\title{
INTERNAL HERNIA ASSOCIATED WITH MECKEL'S DIVERTICULUM IN GERIATRIC PATIENT
}

\author{
Aleksandar Karanikolić, Miodrag Djordjević, Ivan Pešić, Lidija Djordjević, \\ Nebojša Ignjatović, Aleksandar Zlatić, Toplica Bojić
}

\begin{abstract}
This report describes an unusual geriatric case of acute small bowel obstruction (SBO) due to Meckel diverticulum (MD).

We present a 65 year old male with $90 \mathrm{~cm}$ portion of necrotic ileum. Another bowel segment portion with a strong giant MD adherence to the mesentery created a bridge. The mentioned bowel loops went through it, giving rise to an internal hernia.

We want to highlight that internal hernias are not easy to diagnose clinically and abdominal CT images are strongly recommended when suspecting any case of internal hernia in geriatric population.
\end{abstract}

Acta Medica Medianae 2020;59(1):96-99.

Key words: small bowel obstruction, internal hernia, the elderly

Surgical Clinic Niš, Clinical Center Niš, Serbia

Contact: Aleksandar Karanikolić

48 Dr. Zoran Djindjić Blvd., 18000 Niš, Serbia

E-mail: pean@ptt.rs

\section{Introduction}

Meckel's diverticulum (MD) occurs in about 1$3 \%$ of general population and the majority of them are asymptomatic (1). Small bowel obstruction (SBO) caused by MD is very rare and can be rarely seen in everyday clinical practice (2). Giant MD can be defined as MD with increased dimensions compared to those commonly found (3). This report describes the phenomenon of small bowel obstruction in geriatric patient secondary to an adhesion from the distal end of a giant Meckel's diverticulum. The adhesion formed a band that trapped a loop of the ileum.

\section{Case report}

We present a 65 year old male patient with a 2-day history of repeated bile stained vomiting, obstipation, and abdominal distension. He underwent surgery for coronary artery bypass seven years ago. He had been on a regular antihypertensive treatment for 20 years. He described the abdominal pain as crampy, initiated in the epigastrium, passing to the lower abdomen on the second day. Physical exam showed blood pressure to be $160 / 80 \mathrm{mmHg}$, heart rate $84 \mathrm{bpm}$, respiratory rate $24 \mathrm{rpm}$, temperature $37.6^{\circ} \mathrm{C}$. Abdominal examination revealed a soft but distended abdomen and decreased bowel sounds with tenderness in the lower abdominal part. Laboratory tests revealed a high white blood cell count $(19.4 \times 103$ per cubic millimeter) with $85 \%$ segmented leukocytes, an elevated C-reactive protein level $(231.2 \mathrm{mg} / \mathrm{L})$. Plain abdominal radiograph showed gaseous distension of the small bowel. $A b-$ dominal sonography showed fluid-filled dilated small bowel loops. The abdominal cavity was explored finding serohematic fluid. Ischemic and necrotic signs in an ileum segment were detected. A $90 \mathrm{~cm}$ portion of the ileum with ischemic and necrotic features was identified at $1.5 \mathrm{~m}$ from the ileocecal valve. Moreover, we found that another bowel segment portion with a strong giant MD adherence to the mesentery created a bridge. The mentioned bowel loops went through it, giving rise to an internal hernia. Hence, the strangulation of the bowel segment leading to an ischemic process (Figure 1). The mesenteric adherence was partially liberated afterwards, allowing the intestinal hernia reduction (Figure 2). The ischemic and necrotic bowel portions were resected and intestinal anastomosis was done afterwards. At the end of the procedure the necrotic bowel samples were sent to the pathology department. We performed the resection of MD in order to prevent the possibility of further complications. 


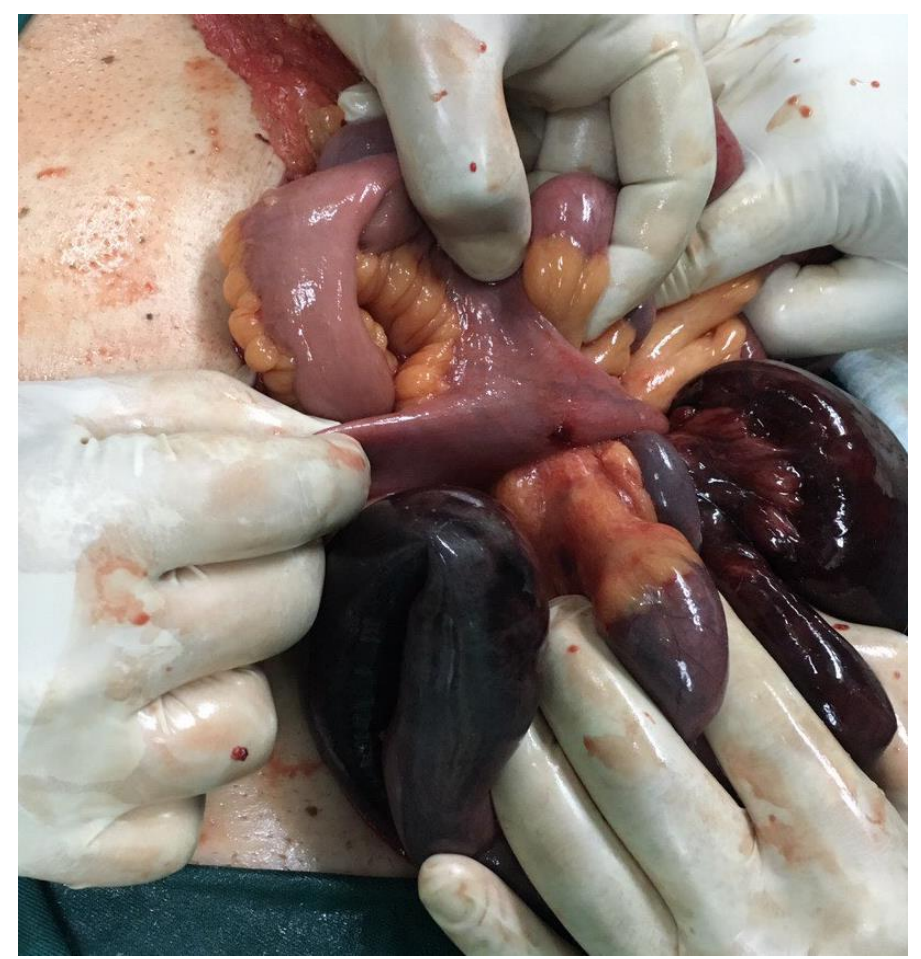

Figure 1. Strangulation of the bowel segment leading to an ischemic process in the internal hernia

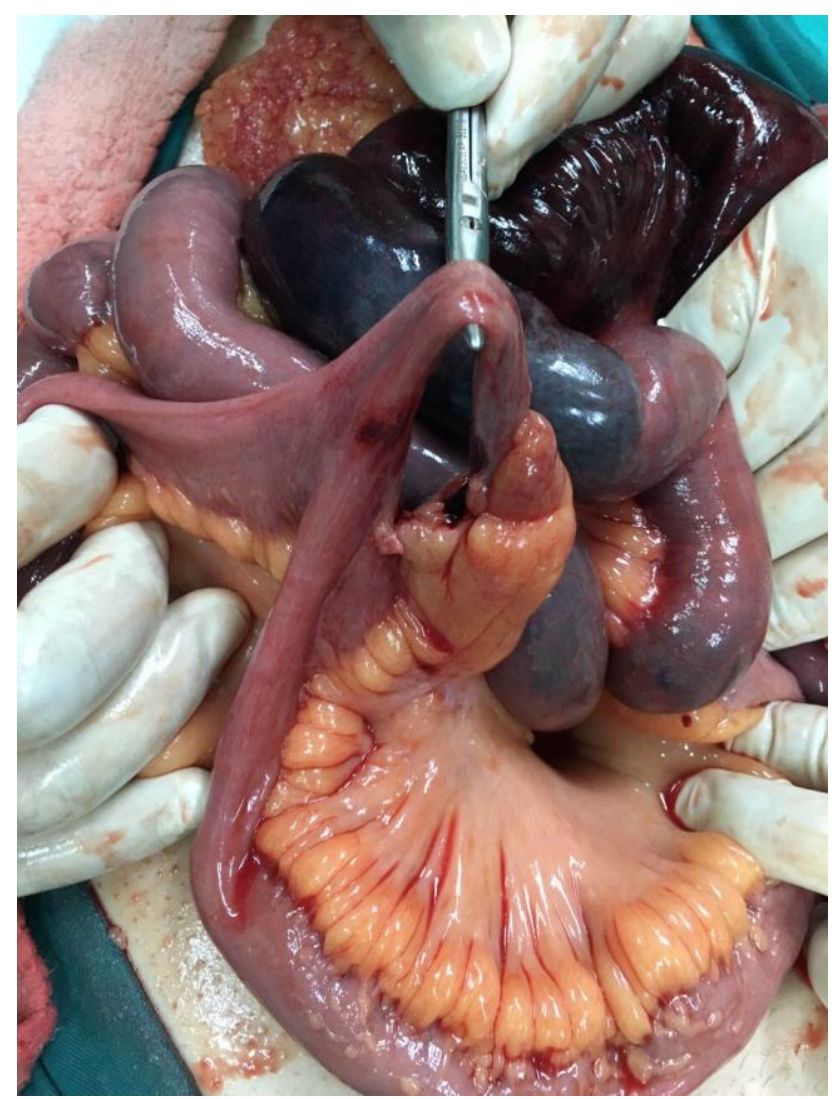

Figure 2. Giant Meckel's diverticulum formed the opening of internal hernia 


\section{Discussion}

Patients with Meckel's diverticulum have the lifetime risk of complications of around $4 \%$ (4). Complications due to Meckel's diverticulum include hemorrhage, intestinal obstruction, diverticulitis, Littre's hernia, umbilicus sinus, and tumours (5). Intestinal obstruction is the most common complication in adults and gastrointestinal haemorrhage is the most common complication in children. Intestinal obstruction caused by Meckel's diverticulum can occur for several reasons: by entangling a loop of small bowel around a fibrous cord or within a mesodiverticular band, intussusception, volvulus, incarceration within a hernia sac (Littre's hernia), chronic Meckel's diverticulitis, foreign body, or neoplasm (4). Clinically, intestinal obstruction can be asymptomatic or cause significant discomfort ranging from constant vague epigastric pain to intermittent colicky periumbilical pain. Additional symptoms include nausea, vomiting and recurrent intestinal obstruction. Symptom severity relates to the duration and reducibility of the internal hernia and the presence or absence of incarceration and strangulation (1).

Imaging studies often play an important role in the diagnosis of internal hernias caused by various etiological factors, because they are often difficult to identify clinically. Native abdominal radiography and ultrasound had no interest in setting up adequate diagnosis. These diagnostic procedures showed a picture of acute intestinal obstruction. However, abdominal CT has become the first-line imaging technique in these patients because of its availability, speed, and multiplanar reformatting capabilities. Unfortunately, in this case, we did not use the abdominal CT in the diagnosis, which proved to be a bad decision. However, one should take into account that in our hospital abdominal CT is not used as a standard tool in the diagnosis of intestinal obstruction.

Meckel's diverticulum is traditionally considered a pediatric disease that is associated with intestinal hemorrhage or perforation. Meckel's diverticulum complicated with internal hernia presenting as an intestinal obstruction is exceedingly rare (5).
Jain and Viswanath (2013) (6) reported case of small bowel obstruction due to a Meckel's diverticulum complicated with internal hernia in a 60 year old male patient.

Fuentes-Diaz et al. (2015) (3) presented a 19 year old male with acute abdominal pain suggestive of appendicitis. During appendectomy, they discovered ischemic and necrotic signs in a bowel segment, leading them to perform a laparotomy that revealed a portion of ischemic and necrotic jejunum, and another bowel segment with a strong adherence to the mesentery root that created an internal hernia. The internal hernia was reduced and the injured bowel portions were resected.

Devanaboyna et al. (2008) (7) presented MD causing mechanical small bowel obstruction in a 33 year old gentlman. The MD and adhesion were excised with translinear cutting stapling device and the no ischemic small bowel was decompressed.

Meckel's diverticulum as a cause of SBO in elderly patients is very rare. The specificity of this case is that MD was not part of gangrenous or inflammatory affected small bowel loops. For this reason $M D$ should be considered as the cause of SBO in the geriatric population. Whenever we have a dilemma regarding the etiology of SBO, CT examination of the abdomen should be done.

A timely and accurate diagnosis of intestinal obstruction in elderly patients caused by giant MD in clinical practice is not simple. Abdominal CT images are strongly recommended when suspecting any case of internal hernia in geriatric population in order to prevent intestinal gangrene.

\section{Conflict of Interest}

The authors declare no conflicts of interest

\section{Statement of Ethics}

The research was conducted ethically in accordance with the World Medical Association Declaration of Helsinki. Guardian of the subject gave the informed written consent to participate in this research. 
References

1. Al Jabri KA,El Sherbini A. Small bowel obstruction due to Meckel's diverticulum: acase report. Oman Med J 2012;27(1):1-3. [PubMed]

2. Elsayes $\mathrm{KM}$, Menias $\mathrm{CO}$, Harvin $\mathrm{HJ}$, Francis IR. Imaging manifestations of Meckel's diverticulum. ARJ Am J Roentgenol 2007;189(1):81-8.

[CrossRef] [PubMed]

3. Fuentes-Diaza JM, Trujillo-VasquezC CA, ParraVargasd AM, Andrea Sofía Rovira-Chaves AS, TinocoGuzman LV, Garcia-Garcia JM. Strangulated internal hernia by giant Meckel diverticulum presented as acute appendicitis. Int J Surg Case Rep2015;13:61-3. [CrossRef] [PubMed]

4. Cartanese C, Pettiti T, Marinelli E, Pignatelli A, Marginetti $D$, Zuccarino $M$, et al. Intestinal obstruction caused by torsed gangrenous meckel's diverticulum encircling terminal ileum. World J Gastrointest Surg 2011;3(7):106-9.[CrossRef] [PubMed]

5. Papaziogas $B$, Makris I, Tsiaousisp $P$, Chatzimavroudis G, Paraskevas G, Atmatzidis K. An unusual case of intestinal obstruction caused by a Meckel's diverticulum. Aristotle University Medical Journal 2007; 34 (1):55-9.

6. Jain AKC, Viswanath $\mathrm{S}$. Acute intestinal obstruction due to Meckel's diverticulum: a case report. Int Med Case Rep J2013;2013:1-3.[CrossRef]

7. Devanaboyna G, Singh-Ranger D, Shami S. Meckel's diverticulum causing mechanical small bowel obstructtion. Can J Surg 2008;51(2):156.[PubMed]

\title{
UNUTRAŠNJA INKARCERACIJA UZROKOVANA MECKELOVIM DIVERTIKULUMOM KOD BOLESNIKA STARIJEG ŽIVOTNOG DOBA
}

\author{
Aleksandar Karanikolić, Miodrag Đorđević, Ivan Pešić, Lidija Đorđević, \\ Nebojša Ignjatović, Aleksandar Zlatić, Toplica Bojić
}

Klinika za opštu hirurgiju, Klinički centar Niš, Niš, Srbija

Kontakt: Aleksandar Karanikolić

Bulevar dr Zoran Đinđić 48, 18000 Niš, Srbija

E-mail: pean@ptt.rs

Predstavljamo redak slučaj akutne obstrukcije tankog creva uzrokovane Meckelovim divertikulumom (MD) kod bolesnik starijeg životnog doba.

Prikazan je bolesnik star 65 godina, kod kojeg je verifikovan nekrotični ileum u dužini od $90 \mathrm{~cm}$. Dugačak MD slepljen za mezenterijum tankog creva formirao je otvor kroz koji je prošao deo tankog creva dovodeći do unutrašnje inkarceracije, ishemije i nekroze.

Želimo istaći da unutrašnju inkarceraciju nije lako dijagnostifikovati, te je potrebno uraditi MSCT snimanje abdomena kada postoji sumnja na unutrašnju inkarceraciju, naročito kod bolesnika starijeg životnog doba.

Acta Medica Medianae 2020;59(1):96-99.

Ključne reči: obstrukcija tankog creva, unutrašnja kila, gerijatrijski bolesnici 